\title{
Девичьи любовные рассказы собственного сочинения - романтика, идеалы, примеры, развитие
}

\author{
Эда Калмре \\ Отделение фольклористики, Эстонский литературный музей, \\ Эстония \\ eda@folklore.ee
}

\begin{abstract}
Аннотация: Статья основана на интерактивных любовных рассказах собственного сочинения, собранных в 2010-2014 гг. в блогах эстонских девочек 14-18 лет. В исторической перспективе эти тексты сопоставляются с рукописными рассказами о любви собственного сочинения из девичьих альбомов второй половины XX века. Источником современного материала послужил портал для общения rate.ее и сообщества в Фейсбуке, посвящённые девичьим любовным рассказам. В статье представлен обзор и анализ описания взаимоотношений, романтики, любви, счастья и надежд в девичьих рассказах собственного сочинения. Также в работе рассматривается, насколько соответствуют девичьи фантазии сегодняшним общим концепциям представления романтики, любви и секса.
\end{abstract}

Ключевые слова: альбом, блог, частный рукописный архив, девическая литература, субкультура девичества, Интернет, любовный рассказ, романтика

«Вероника, я хочу у тебя кое-что спросить,» - сказал Карл. «Да?». Вопрос меня настолько взволновал, что я чуть не села. «Вероника, ты бы хотела быть моей девушкой?». От испуга 
счастья я даже расплакалась. Плачущим голосом я ответила: «Конечно, Карл. Хочу!». Он поцеловал меня, и мы спустились вниз. («Жизнь Вероники», часть 9)

Это отрывок из любовного рассказа, в нескольких частях публиковавшегося в 2011 году в блоге одной двенадцатилетней девочки. Посредством рассказов о любви собственного сочинения сотни эстонских девочек заявляют о себе в своих интерактивных блогах. И сайтов, публикующих романтические произведения в форме рассказов с продолжением, становится всё больше. В начале тысячелетия богатое собрание таких рассказов имелось на сайте rate.ее в рубрике дневников девочек. В Фейсбуке (ФБ) сообщества, интересующиеся рассказами о любви, стали появляться пять лет назад, и на сегодня эта коммуникативная сеть достигла большой популярности среди подростков, как пишущих, так и читающих эти рассказы. ${ }^{1}$

Сочинение и чтение любовных рассказов важно с точки зрения развития и взросления девочек-подростков. В детстве они проигрывают романтические ситуации и взаимоотношения с противоположным полом в играх и занятиях, пишут рассказы, гадают о суженом на картах, высчитывают проценты любви и пр. (Anttila 2009, 1996). Юрий Шикаренко подчёркивает значимость практики рукописных любовных рассказов в инициации девочек. Читатели, равно как и авторы рассказов, в определённой мере отождествляют себя с героями произведений, набираются опыта в представленном в этих рассказах мире и затем, уже в реальной жизни и отношениях стараются не повторять допущенных в рассказах ошибок (Шикаренко 1995: 84).

В эстонской традиции ранними примерами для нынешних интерактивных рассказов о любви служат рукописные источники второй половины прошлого столетия. В них любовь нашла отражение не только в романтических рассказиках, но также в стихах, афоризмах, играх-предсказаниях и гороскопах. Особенно активно такие частные собрания, своеобразно украшенные рисунками и вырезками, использовались девочками в 1970-1980-е гг. Девочки играли в предсказания, читали романтические рассказы и стихи на тему любви и отношений, изречения, шутки и пр. В тетрадях, составляемых девочками, со временем сформировался своего рода традиционный репертуар, с небольшими вариациями повторявшийся из тетради в тетрадь. 
Такое увлечение стало формой социального общения среди различных групп девочек. Тетрадями обменивались, полюбившиеся отрывки переписывались (Lipponen 1992; Kalmre 2010).

Ниже я попытаюсь проследить содержательные изменения, происшедшие в вымышленных историях девочек, начиная с рассказов, бытовавших в рукописных материалах в конце прошлого столетия, и заканчивая любовными рассказами собственного сочинения, собранными мной в последние годы в интернет-блогах девочек-подростков на сайте rate.ее и в сети Фейсбук. Изучая образцы, ставшие примером для этих рассказов, их происхождение и трансформацию, я постараюсь раскрыть представления девочек о любви и счастье.

\section{Исследуемый материал}

В нижеследующем сравнительном анализе будут рассмотрены рассказы собственного сочинения девочек из трёх разных источников и двух периодов времени. Рассказы из тетрадей девочек в первом разделе имели распространение преимущественно в 1970-1990 гг. в период советской оккупации. Второй и третий разделы содержат романтические рассказы, опубликованные в интернет-блогах девочек на сайтах rate.eе и Фейсбук в 2010-2014 гг.

1. Любовные рассказы из тетрадей трёх девочек, записанные в последние десятилетия XX века: «Аллан и Вийвьян», «Маннь и Тыннь», «Ринго и Беэта», «Янар и Рена», «Эрки и Катрин», «Слёзы», «Не трогай меня!», «Смерть», «Ты сказал тогда...»².

2. А) Романтические рассказы, собранные на сайте rate.eе в 2010-2011 гг.: «Рассказ о мотоцикле», «Высокомерная девчонка и мальчик», «Современная золушка», «Разбитое сердце», «Марионетка», «Not like the Movies»" «Nobody perfect but you are», «Небольшой рассказ», «Маленький рассказ», «Игры судьбы», «Жизнь не сказка», «Когда-то», «Легко ли влюбиться», «Рассказ о застенчивой девушке, ставшей самоуверенной женщиной», «Боль», «Настоящая любовь», «Tell my way», «JB», «В раю есть любовь», «Тhe lovely lovely lovely». 
B) Рассказы на сайте rate.eе за 2013 год: «This is US», "You belong with me», "New life», "We are a love story... gone wrong», «Don't cry it's over, smile because it happened», «He is not perfect, but he's all I want». ${ }^{4}$

3. Рассказы в сообществах в Фейсбуке за 2013-2014 гг.: «Мегазанимательная жизнь Элис», «Жизнь Элеанор», «Жизнь Элизабет», «Жизнь близнецов», «Жизнь подростков», «Рассказы Шакир», «Занимательная жизнь Мелинды».

Рассказы имеют разные названия и различаются по содержанию и объёму, равно как и были распространены в разных источниках. В девичьих рукописных собраниях конца прошлого столетия (раздел 1) распространение имели в основном короткие рассказы, зачастую содержавшие лишь один эпизод.

По большому счёту, девическую любовную прозу в Интернете (см. А и В раздела 2 и раздел 3) можно разделить на две части. Первую, относительно маргинальную часть образуют различные варианты коротких схематичных рассказов на тему беззаветной трагической любви. Происхождение этих небольших рассказов неизвестно, и они имеют признаки, свойственные фольклору. Вторая часть интерактивных любовных новелл девочек-подростков является их индивидуальным творчеством (Kalmre 2010: 68-69). Они имеют разный объём, но в большинстве своём девичьи рассказы в Интернете - это рассказы с продолжением, наиболее объёмные из которых могут иметь 60-80 и более частей.

На самом деле, rate.eе ${ }^{5}$ и ФБ в определённом смысле также различаются между собой. Каждый автор на сайте rate.eе имеет свой аккаунт, по которому можно установить его личность. Наиболее популярные рассказы о любви на сайте rate.ее и их авторы могли иметь сотни читателей. Авторов рассказов с продолжением в ФБ установить непросто, а круг читателей может быть гораздо шире, достигая в отдельных случаях 4000.

Также рукописные собрания и интернет-рассказы различаются с точки зрения участия в них читателей. Несмотря на то, что в Интернете круг читателей шире и более анонимен, нежели в случае тетрадей, бывших прежде в обращении среди девочек, мы и здесь имеем дело с постоянным закрытым сообществом, предусматривающим такие же твёрдые нормы общения, одобрения и привлечения, как это было раньше в группах девочек, 
обменивавшихся тетрадями. По рассказам с продолжением, частями публиковавшимся в Интернете за последние пять лет, чётко видно, что они всё больше создаются при содействии читателей, в процессе взаимного общения. К примеру, особенностью развития rate.eе в 2013 году было то, что авторы вписывали наиболее преданных франатов (читателей, ставящих лайки, комментаторов) в свои рассказы в качестве действующих лиц, давая им имена и придумывая поступки. В ФБ инициатор сообщества является одновременно и собственником, имеющим нескольких помощников (боссов), а читатели, предложившие наиболее интересные сюжеты для продолжения истории, могут получить права администратора и возможность самим написать одну из её частей.

Анализ развития практики создания девочками любовных рассказов в Интернете указывает на то, что это их коммуникативная игра, процесс, в котором общение участников даже важнее финала самого рассказа.

\section{Любовь, счастье, боль, слёзы, смерть в девичьих рассказах прошлого столетия}

Девичьи рукописные рассказы о любви классифицируются исследователями как явление, пограничное между литературой («индивидуальным наивным литературным творчеством») и (альбомным) фольклором (Борисов 1992, 2002; Жаворонок 1998). Основной темой девичьих рукописных рассказов второй половины прошлого века выступает самоотверженная любовь, а истории завершаются гибелью одного или обоих героев. Как правило, рассказы имеют незамысловатое содержание и трёхчастную фрабулу: 1) встреча и зарождение любовного чувства, 2) испытание на верность, 3) трагический фринал. Также в рассказах может встречаться мотив несчастного случая или немилостивой судьбы. Помимо основной трагической направленности, в девичьих рассказах возможен и счастливый финал, при котором первая любовь не погибает. Это говорит о влиянии на них сказочной и мелодраматической традиций. В фрабульный архетип девичьих мелодраматических романтических текстов прошлого столетия входят также «текст в тексте» и предсмертное письмо юноши своей возлюбленной (Борисов 2002: 296-297). 
Некоторые русские исследователи связывают возникновение жанра девичьих рукописных любовных рассказов с романтической эпохой 1950-1960-х годов в Советской России. По мнению других, как неофициальная и неканоническая форма фольклора они бытовали намного раньше, но не собирались и не изучались, и поэтому многое об этом жанре просто-напросто утрачено (Борисов 2002: 286).

Собранный в Эстонском фрольклорном архиве эмпирический материал позволяет предположить, что девичьи рукописные рассказы о любви стали распространяться здесь лишь в послевоенное время и обрели популярность в 1960-1970-е годы, когда девочки стали переписывать их друг у друга. И если в русской советской традиции исследователями обнаружено по меньшей мере 38 сюжетно различающихся текстов (Борисов 1992; Борисов 2002: 285), то на основе собрания рукописных альбомов в Эстонском фольклорном архиве можно сказать, что традиция рукописных рассказов о любви среди эстонских девочек уступала по разнообразию формы и содержания таковой у русских школьниц XX века. Также рукописные любовные рассказы эстонских школьниц значительно меньше по объёму и проще. Обычно внимание сосредотачивается на одной-двух романтических встречах основных действующих лиц, которые могут закончиться трагично (Kalmre 2010: 231-232).

Связывание любви со страданиями и смертью было актуальным во времена раннего модерна и в эпоху модерна. Саймон Гаант, рассуждая о мотиве смерти ради любви, популярном в языковом и образном мире средневековой любовной литературы, отмечает, что во Франции содержащие этот мотив песни, романсы и рассказы формировали влиятельную литературную традицию и были весомой составляющей культуры ухаживания уже в XII-XIII вв. (Gaunt 2006). Девичьи мелодраматические рассказы второй половины XX века сравнимы также с бульварной литературой XVIII-XIX вв. В ней также часто встречаются неравные пары, а девушка, принадлежащая к низшему социальному классу, как находит свою любовь, так и добивается успеха и достатка. Из более поздней литературной классики подобную же идею несут и относятся к той же девичье-женской литературе, например, «Гордость и предубеждение» Джейн Остин и «Джейн Эйр» Шарлотты Бронте. Многим из этих рассказов и романов весьма характерен текст от первого лица или 


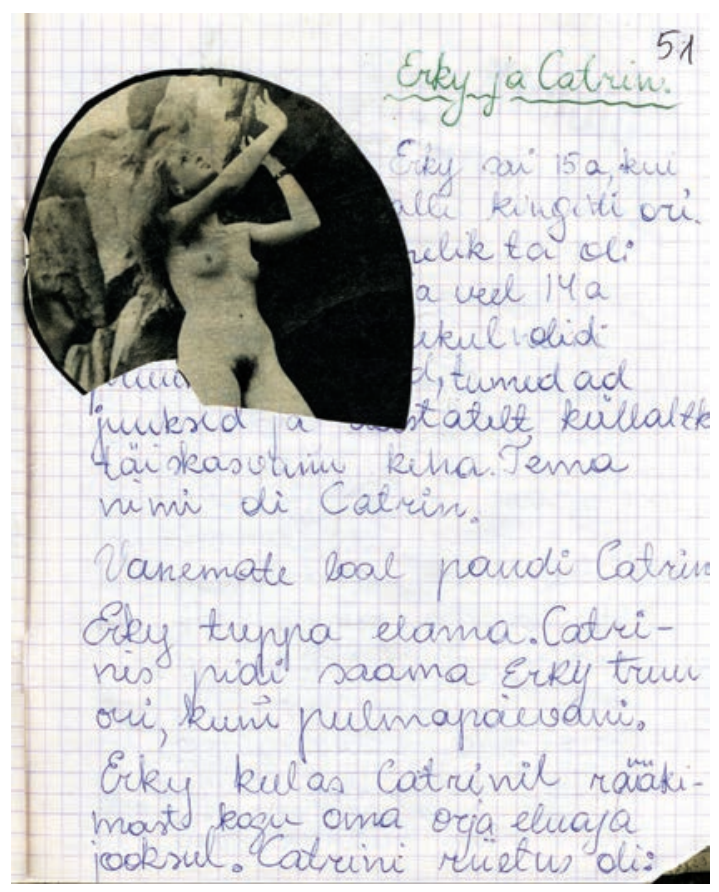

Эрки и Катрин: романтическая история со счастливым концом: «Только смерть сможет разлучить их. Еще одним доказательством этого были близнецы, которые родились у них год спустя, и СЧАСТЛИВАЯ ЖИЗНЬ, которую они разделили с тех пор!» Источник: Veskus, Tuuli, рукопись 1987, EFA, AK 161, 51, Эстонский фрольклорный архив, Тарту.

в форме дневника, что как раз можно считать одной из особенностей девичьей и женской литературы (Mattheus 2010). Главным же литературным образцом любовной истории с трагическим финалом является «Ромео и Джульетта» Уильяма Шекспира.

Учитывая всё вышесказанное, 9 романтических рассказов из эстонских девичьих рукописных собраний последних десятилетий XX века, относящихся к представленному мной первому разделу («Аллан и Вийвьян», «Маннь и Тыннь», «Ринго и Беэта», «Янар и Рена», «Эрки и Катрин», «Слёзы», «Не трогай меня!», «Смерть», «Ты сказал тогда...»), видятся весьма показательными и типичными для эпохи. В большинстве из них представлена простая история о встрече девушки и юноши с точки зрения девушки. 


\section{Слёзы}

Мы познакомились на последней вечеринке. Наши глаза случайно встретились. Через несколько минут ты поклонился мне. Было хорошо танцевать с тобой. Я чувствовала тепло твоего тела и горячую щеку, прильнувшую к моим волосам. Внезапно ты вздрогнул, щека оторвалась от волос, и ты посмотрел мимо меня куда-то вдаль. Следующий танец ты подарил другой девушке. Я и раньше видела тебя с ней. Вы станцевали танец, в ответ на который ты получил победоносную улыбку. Мне показалось, что в тебе есть что-то неприятное. Я не могла больше смотреть на вас. Я вышла и побежала к раздевалке. Слёзы заливали мне глаза. Вдруг чья-то рука коснулась моей спины. Я не смела обернуться, потому что знала, что это был ты. Ты встал передо мной, улыбнулся, молча вытер мои слёзы.

Прекрасны слёзы, которые вытирает любимый!

Как правило, несчастье случается с юношей, а девушка лишь кротко страдает. Об этом мелодраматические рассказы «Смерть», «Аллан и Вийвьян», «Маннь и Тыннь», «Янар и Рена».

В тот раз ты велел мне уйти с твоего пути. Ты кричал на меня. Я стояла перед тобой, опустив голову, стояла, а по щекам текли слёзы. Одна слеза упала на моё белое платье, и ты заметил это. Ты бросился передо мной на колени и прошептал: «Уходи». Я повернулась и ушла. Я не оборачивалась, потому что боялась, что моё сердце разорвётся, но оно не разорвалось. А вчера ты пришёл! Ты стоял передо мной, склонив голову, как я в прошлый раз, только ты не плакал. Ты попросил, чтобы я приняла тебя назад. Я сказала: «Нет». Ты бросился передо мной на колени, а я прокричала: «Нет!»

Ты стал уходить, но обернулся у двери, и я увидела, что ты плачешь. И теперь я бы приняла тебя обратно, но ты не сказал ни слова и ушёл.

Утром, открыв дверь, я увидела тебя сидящим за дверью. Рубашка раскрыта, а кровь на груди давно застыла. ТЫ БЫЛ MËPTB!

Рассказ «Смерть» в некотором смысле исключителен. Это даже не рассказ, а монолог девушки, в котором «жизнь полна страданий и мучений из-за любви, её венчает смерть, насыщенная ароматом огненно-красных роз, слёз и поцелуев, и причиной всему ты, моя голубоглазая белокурая любовь». Приём «текста в тексте» и предсмертное письмо юноши представлено в рассказах «Аллан и Вийвьян» и «Янар и Рена». 
Впрочем, не все упомянутые рассказы первого раздела заканчиваются трагически, т. е. смертью одного или обоих героев. По меньшей мере в двух рассказах («Янар и Рена», «Эрки и Катрин») действующие лица подвергаются определённым испытаниям, но их история имеет счастливый финал - «Рена и Янар остались вместе навсегда», Эрки и Катрин «не могло разлучить ничто, кроле слерти. Подтверждениел толу родившиеся спустя год двойняшки и прожитая влесте СЧАСТЛИВАЯ ЖИЗНЬ!»

В Эстонии не зафиксировано описаний бытования практики любовных рассказов в девичьих компаниях. Однако, например, Сергеем Борисовым представлены некоторые описания самих девочек о чтении любовных рассказов: «Писали, читали рассказы о любви: “Любовь Тани и Эдика”, “Два лебедя” и др. [...] Этими рассказами лет в 13-14 я очень увлекалась, да и не только я, но и мои сверстницы. Мы их переписывали, собирались вместе, читали, плакали» (Борисов 2002: 293).

Почему же подобные рассказы были настолько популярны во второй половине XX века именно среди советских девочек? Безусловно, они имели особое значение в эмоциональном воспитании девочек советского времени. Сравнительного исследования подобного рода ещё не проводилось, но можно предположить, что в силу недостаточной доступности материалов на любовную тему и определённой манеры представления чувственного мира в литературе и фильмах девичьи письменные материалы второй половины XX века стали такими разнообразными. ${ }^{6}$ Я и сама, будучи девочкой в то время, помню, какое влияние имели на меня и моих подруг индийские мелодраматические фильмы, показывавшиеся в сельском кино. В то время это были практически единственные фрильмы, доходившие до советского зрителя, в которых изображалась настоящая, верная, самоотверженная любовь. "Барышни, воспитанные на индийскол кино» - так говорили о девочках моего и нескольких последующих поколений (Корсаков 1994; Борисов 2002: 290). Тот фракт, что молодёжь учится манерам и навыкам романтического поведения именно из кино, отмечался уже в начале прошлого века (Illouz 1997: 33).

Бесспорно, ни одно явление нельзя рассматривать отдельно от общего культурного контекста. Так, появление практики девичьих рукописных любовных рассказов может быть связано с либеральными поведенческими реформами 1950-1960-х годов, 


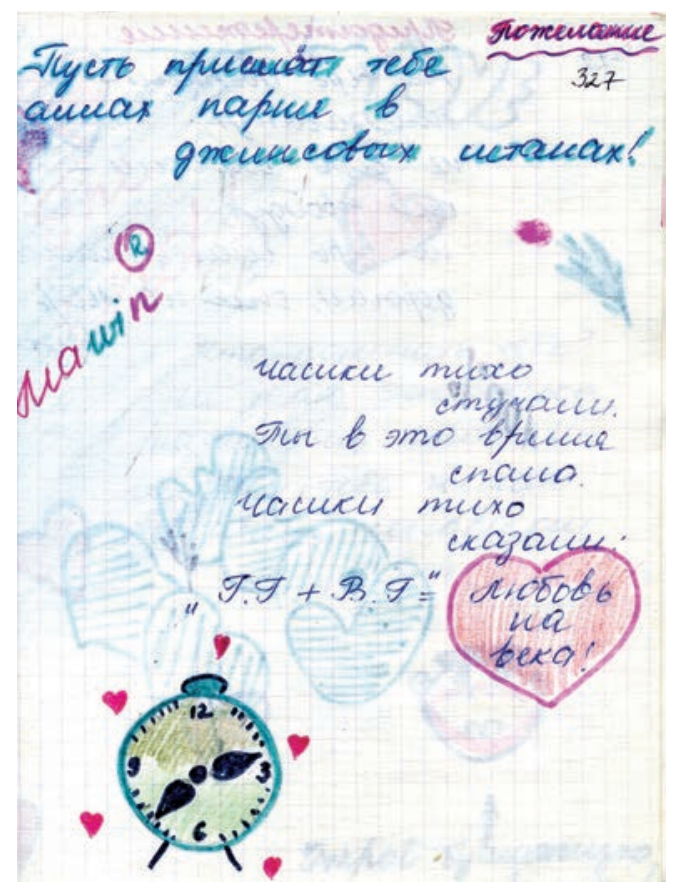

Дизайн типичной страницы из девичьего альбома. RKM KP 55, Таня Петухова, 1980 г.p.

проводившимися в России во время правления Никиты Хрущёва. В эту «эпоху романтики» в СССР стали меняться формы сексуального поведения, свадебные ритуалы, упростился процесс развода, значимым стал сам человек со своими физическими и эмоциональными потребностями (Лебина 2014).

Приравнивание любви к самоотверженности и смерти нельзя считать феноменом только прошлого столетия. Такая же эмоциональная шкала в небольшой степени проявляется и в девичьих интернет-рассказах первого десятилетия XXI века. Так, в 2010-2011 гг. на rate.eе были популярными рассказы «Высокомерная девчонка и мальчик» и «Рассказ о мотоцикле». Они копировались, постились, читались и оценивались в блогах девочек снова и снова. В первом рассказе юноша во имя любви жертвует своими глазами и зрением. Во втором рассказе юноша с девушкой едут на мотоцикле, и он отдаёт свой шлем 


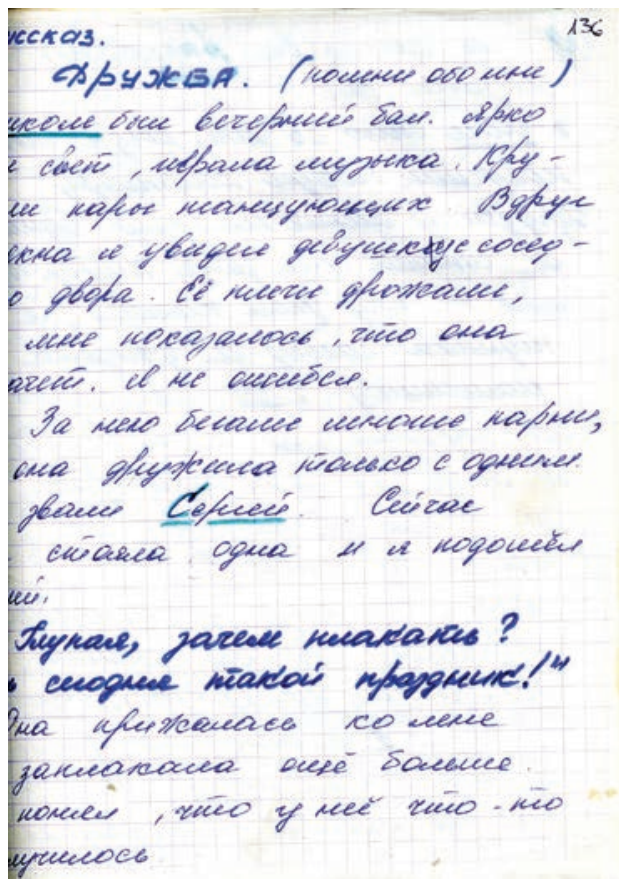

История «Дружба». RKM KР 57, Ирина Арокопова, 1978 г.р.

ей, поскольку знает о неисправных тормозах у мотоцикла. «На следующий день в газете было напечатано: "Из-за неисправности торлозов мотоиикл врезался в здание. Молодой человек погиб, девушка спаслась". На салол деле, юноша ешё во вреля езды понял, что торлоза не работают. Но он не хотел, чтобь об этол знала девушка. Влесто этого он попросил девушку сказать, что та его любит, и в последний раз почувствовал её объятия. Юноша отдал свой шлел девушке, пусть даже это означало для него смерть. Это и есть любовь...».

В моей выборке такой же трагической направленности, свойственной рукописным романтическим рассказам прошлого столетия, придерживается, например, «Небольшой рассказ», опубликованный на rate.ee. В этой истории мальчик не отвечает на чувства девочки, он пишет ей письмо и предлагает лишь дружбу, а девочка от боли и тоски кончает с собой. ${ }^{7}$ 


\section{Эротика и секс в рассказах девочек}

Для субкультуры девичества весьма характерны игры с сексуальными франтазиями, а рукописные тексты, описывающие эротические и сексуальные отношения, уже в начале XX века использовались в девичьей культуре как совершенно отдельные жанры наряду с романтическими текстами (Kalmre 1997; Борисов 2002: 303). Именно как отдельные жанры, и этим данная письменная практика подкрепляет идею классических художественных произведений прошлого века, в которых имели место быть, скорее, сенсуальность и, возможно, эротика, но никак не секс, т. е. в литературе секс и романтические чувства были разделены. Романтическая любовь выше, а сексуальность не романтична (Illouz 1997: 106; Illouz 2013). На это же явление в девичьих рукописных романтических рассказах XX века указывал и С. Борисов, сообщая, что фризическая любовь и эротика представлены лишь в 5-10\% рукописных рассказов русских девочек. В советское время подобных публичных текстов и не могло быть много, но они были. Например, среди русских советских девочек был очень популярен рассказ "Баня» ${ }^{8}$. Его копировали и читали поодиночке или в компании девочек тайком, спрятавшись от родителей (Борисов 2002: 298, 303).

Тем не менее, среди представленных мной рукописных рассказов последних десятилетий прошлого века имеются и такие, в которых любовь не исключает секса. Таковы рассказы «Маннь и Тыннь» и «Ринго и Беэта». Трагична история Маннь и Тыння, в которой большая романтическая любовь означает именно физические взаимоотношения двух главных героев, а основное содержание заключается в детальном представлении постельных сцен. Но и эта история с трагическим финалом демонстрирует величественность любви, а большая любовь получает окончательное подтверждение в лице смерти: «После тяжёльх родов Маннь улерла. После её слерти Тьннь покончил с собой, так как не мог жить без Маннь. Так закончилась счастливая-несчастная любовь двух молодьх людей».

Из вышесказанного явствует, что в отдельных случаях в девичьих рукописных романтических рассказах последних десятилетий XX века всё-таки могли быть упоминания о сексе, но среди предложенных мной интерактивных примеров (разделы 
2 и 3) соответствующие детальные описания отсутствуют. Вероятно, для переживания подобных чувств и формирования сексуального идентитета девочек в современной культуре имеются и другие возможности, поэтому в XXI веке этот жанр полностью исчез из девичьих блогов. Интерактивным рассказам девочек характерны, скорее, скромные любовные сцены, а также лёгкая эротика, почти никогда не кульминирующаяся описанием совокупления. По определённым текстовым сигналам читатель догадывается о страсти героев, об их взаимных романтических чувствах, о которых они в конце концов и сами узнают, несмотря на подчас сложные взаимоотношения.

Мы решили поиграть в карты. Я против него. Играли в «Верю-не верю». Это было ужасно. Каждый раз выпивали по стопке. Всё время пялились в глаза друг другу. И всё время находились очень близко друг к другу. Напряжение росло, и я выронила две карты под стол. Я полезла их подобрать и увидела перед собой Его. Мы посмотрели друг на друга... он прильнул своими губами к моим...» («How could I let him walk out of my life») ${ }^{9}$.

Страсть (desire) в классической романтической литературе выступает в качестве важной побуждающей силы. Она выражается не столько в словах, сколько во множестве текстовых сигналов. Возбуждая, избегая, дразня, эти тексты вызывают у читателя страсть, которая обрамляется метафорами, сформировавшимися в любовных рассказах XIX-XX вв., такими как лунный свет, шум моря, звёздное небо и т. п. Для описания первой встречи и романтических чувств главных героев в рассказах создаётся специальная атмосфера, к примеру, описываются падающие на подоконник капли воды, свет от свечи, красивая музыка и т. п. (Belsey 1994).

\section{Романтика, идеалы и примеры в интерактивной любовной прозе XXI века}

Девичьи интерактивные любовные рассказы собственного сочинения во многом отличаются от своих фольклорных предшественников конца XX века. Последние представляли собой короткие схематичные рассказы с мелодраматическим или трагическим финалом, повествовали о первой встрече девушки 
и юноши и зарождении любовного чувства, тогда как в рассказах с продолжением начала XXI века говорится о повседневной жизни девушки, её друзьях, отношениях и мечтах. В основном это рассказы от первого лица, и действие происходит, как правило, в привычной для девушки среде: дома, на улице, в школе, на вечеринках и пр. В рассказах много диалогов и большое количество действующих лиц: родители девушки, братья и сёстры, подруги, знакомые мальчики. Девушки в роли главных действующих лиц этих рассказов соответствуют образу женщины современного новомодного мира, являясь, как правило, самостоятельными и экономически независимыми. Их родители обычно успешны или не вмешиваются в жизнь дочерей, например, надолго уехали за границу, или, наоборот, сама девушка переехала жить к богатому родственнику за границу, или же это вовсе сводная семья, где помимо детей каждого из родителей имеются ещё и общие дети.

Привет, меня зовут Эмили Розенберг. Мне 15 лет, у меня длинные светлые волосы, стройная фигура и синие глаза. Я живу в Нью-Йорке в большой двухэтажной квартире. Мою маму зовут София Розенберг. У неё тёмно-русые волосы, ей 34 года и у неё своя фирма. («Valu») ${ }^{10}$.

В рассказах хорошо вырисовываются типажи романтических героев. Девушки в них стройные, статные, привлекательные, модные, с длинными волосами, юноши высокие, с натренированным телом и мужественной внешностью. В некоторых рассказах девушки используют узнаваемые содержательно-стилистические приёмы и повествовательный стиль, характерный для сказок. Среди моих интерактивных рассказов о любви имеются также, например, истории о золушке или гадком утёнке, содержание которых заключается в обретении отверженной по какой-то причине (из-за внешности, положения и пр.) девушкой любви и счастья. Это, например, «Рассказ о застенчивой девушке, ставшей самоуверенной женщиной» и «Игры судьбы».

Первая встреча с юношей своей мечты описывается, как правило, романтично и в деталях:

Был тёплый летний вечер. Я смотрела на море и изумительный закат. Поверхность моря была зеркально гладкой и переливалась. Я играла песком, тиская его в руках. Он был мягкий, как пух. Вскоре солнце скрылось, и я решила пойти домой. Не- 
ожиданно я увидела того, в кого влюбилась с первого взгляда. У тебя были светло-русые вьющиеся волосы, развевающиеся на ветру. Твоё коричневое натренированное тело привлекло моё внимание. Твои лучезарные зелёные глаза открыли моё сердце. («В раю есть любовь») ${ }^{11}$.

Кэтрин Белси в качестве одной из характеристик художественных рассказов о любви выделяет взаимный антагонизм главных героев, часто имеющий место быть в начале рассказа. Он перерастает во взаимную симпатию, о которой читатель догадывается прежде, чем это осознают сами герои (Belsey 1994: 21-22). Это вызывает у читателя чувство удовлетворения от осуществления заветных желаний, в чём и заключается одно из наслаждений от чтения романтических рассказов. $К$ примеру, в рассказе «You belong with mе» всё происходит так, как и следовало ожидать, пари двух девушек заканчивается зарождением любовного чувства. ${ }^{12}$

Несмотря на то, что в рассказах часто описываются поиски себя и разные взаимоотношения главных героев, в моей выборке любовные истории в блогах девочек на rate.ее обычно заканчиваются счастливо: любовь обретена и подтверждена с обеих сторон, более того, многие рассказы заканчиваются свадьбой и созданием семьи. Конечно, отклонения от этой основной линии также имеются («How could I let him walk out of my life») $)^{13}$.

Ева Иллуз в своём исследовании отмечает, что в наше время детали роскоши имеют смысловое значение в общем культурном сценарии изображения любви (Illouz 1994: 24). На основе моих материалов также можно утверждать, что в интерактивных романтических рассказах девочек всё более значимым становится описание красивой, шикарной жизни. Также можно отметить, что в последние два года девичьи рассказы в качестве любовных историй стали слабее и менее чётко выражены, тексты вязнут в деталях повседневной жизни, девушки больше не выражают любовь, а пребывают «в отношениях", и часто бывает так, что в ходе длинного рассказа с продолжением они несколько раз меняют партнёров. И многие вышеупомянутые приёмы художественных рассказов о любви (описание страсти, первоначальный антагонизм героев и др.), а также изображение романтических отношений больше не проявляются настолько ярко. При этом именно рассказы в сообществах девушек в ФБ 
в качестве романтических историй слабее и менее выражены, чем соответствующее творчество на rate.eе за 2010-2013 гг.

В то же время в рассказах в ФБ имеется множество ссылок на примеры из современных медиа и поп-культуры. Действие в них всё чаще происходит не только в Эстонии, но и за рубежом: в Америке, Англии, Ирландии и пр. И если девичьи любовные рассказы в рукописных собраниях последних десятилетий прошлого столетия иллюстрировались в основном вырезками из советских журналов моды, то скопированные в Интернете фотографии, добавленные к рассказам на rate.eе и в ФБ, приобретают всё большее значение. Они также служат средством для создания иллюзии роскоши и красивой жизни. Девочки описывают повседневную жизнь героев своих рассказов вплоть до бытовых деталей, словно они бумажные куклы или Барби, чей гардероб можно легко поменять, выбрав в сети картинки с одеждой модных брендов. В фотографиях из Интернета представлена не только одежда девочек, но и модная обувь, аксессуары, причёски, макияж и еда. На снимках, подобранных к рассказам, можно видеть, что герои романтических историй живут в шикарных квартирах и домах, ездят на роскошных автомобилях. Важную роль играют также, например, шопинг и показы известных торговых марок (Cucci, Prada и многие др.) (см. «Жизнь Элеанор», «Рассказы Шакир» ${ }^{14}$ и др.). В жанровом плане рассказы в ФБ разнообразнее, варьируясь от приключенческого рассказа («Жизнь близнецов»15) до пародии («Мегазанимательная жизнь Элис»).

В рассказах 2013-2014 гг. действующие лица также фигурируют в виде иллюстраций. Для изображения главных и второстепенных героев специально подбираются фотографии в сети. Весьма часто девушки выбирают для своих рассказов популярных артистов, певцов и моделей. В некоторых сообществах в ФБ читатели также могут принимать участие в подборе подходящего образа (например, «Занимательная жизнь Мелинды» ${ }^{16}$ ). Выбор парня своей мечты даёт некоторое представление о непрестанно меняющейся культуре франатов. Привлечение представителей поп-культуры, мотивы моды и роскоши в девичьих рассказах имеют своё обоснование. Согласно мнению Евы Иллуз, связывание известных артистов, певцов и др. с романтической культурой способствует легитимизации современных взаимоотношений любви и потребления. Посредством коммер- 
ческой рекламы звёзды усиливают связь между романтикой и идеалами красоты, ведь для рекламы косметических товаров они «одалживают» свои лица и тела. К тому же, многие известные по рекламе звёздные пары являются парами не только на экране, но и в жизни. В их лице потребительская культура сконструировала идеальную пару, так как в них скомбинированы красота, молодость, гламур, здоровье и потребление (Illiouz 1997: 24-25, 89). Линда Дег также указывает на идеал вечного счастья, любви, брака и здоровья в рекламе, ориентированной на женщин, что зарождает в потребителе веру в то, что одежда, косметика, духи, причёска и украшения являются первостепенными средствами привлечения мужчин (Dégh 2003: 39).

Романтическими идеалами многих авторов и читательниц в рассказах на rate.eе за 2009-2010 гг. были американский певец Николас Джонас («Tell my wу») и канадский певец Джастин Бибер («ЈВ»). В рассказе «ЈВ» счастливый конец означает свадьбу с Джастином Бибером. В последние годы главными действующими лицами в рассказах девушек выступают участники популярного англо-ирландского бой-бэнда One Direction (см. «Жизнь Элизабет» в ФБ и рассказы «Don't let me go», «This is us», "New life», "You belong with me», "We are a love story... gone wrong» на rate.ee). Несмотря на многие новые мотивы и направления в девичьих рассказах, свадьба и брак по-прежнему остаются желаемой развязкой историй и критерием наивысшего счастья. В финале упомянутых выше рассказов («You belong with mе» и «We are love story... gone wrong») девушки находят принца своей мечты - участника группы One Direction Гарри Стайлза, а об их блистательной романтической свадьбе свидетельствуют иллюстрирующие рассказ фотографии с изображением невесты в белом пушистом платье и прочих свадебных аксессуаров («We are a love story... gone wrong»). ${ }^{17}$

\section{Заключение}

Обобщая всё изложенное выше, можно сказать, что в случае любовных рассказов собственного сочинения мы имеем дело с естественной и постоянно приобретающей новые черты формой самовыражения в субкультуре девичества. Вне зависимости от времени, среды и контекста, девушки определяют 
свою жизнь и идентитет посредством романтической культуры, сочиняя романтические рассказы, читая их и принимая участие в процессе их написания. Заставляет задуматься тот факт, что рукописные тексты с наивной манифестной дидактикой, бытовавшие ранее в узких кругах девочек и до появления Интернета остававшиеся относительно скрытыми от взрослых, благодаря Интернету нашли своё место в более широком мире, в котором авторов и читателей рассказов о любви несравнимо больше, и эта практика становится частью группового поведения и общения всё большего количества девочек-подростков. Девушкиавторы сочиняли романтические рассказы, опираясь на свою франтазию и способности, придерживаясь стереотипов и клише, приобретённых в литературе и современной массовой и потребительской культуре. Интернет предлагает авторам и читателям рассказов множество возможностей для миксования различных образов и форм цифровых медиа. Согласно утверждению С. Борисова, «девичьи рукописные рассказы о любви выступают и как своеобразный социокультурный институт. От поколения к поколению они транслируют в латентной форме романтические ценности и представления, выполняют для читательниц фрункцию “самоинициации”» (Борисов 2002: 297).

Выявляющиеся в рассказах представления девочек о романтике и любви в последние десятилетия претерпели изменения. В девичьих рукописных рассказах последних десятилетий $\mathrm{XX}$ века доминировал идеал самоотверженной любви, зачастую любовь связывалась со смертью, и это было скорее трагическое, нежели счастливое чувство. А в вышеупомянутых интерактивных рассказах, несмотря на наличие единичных чувственно-трагических примеров среди них, отчётливо угадывается тенденция, свидетельствующая о том, что рыцарство, самоотверженность и смерть во имя любви в девичьих романтических рассказах XXI века больше не актуальны.

Тема любви и романтики в XXI веке тесно связана с потреблением и массовой культурой. Девушки в роли главных действуюших лиц самостоятельны, хорошо одеты, успешны, красивы, вольны действовать и путешествовать по всему миру. И если в мелодраматических историях конца XX века героиня не имела выбора, и лишь один был единственно правильным для неё, то героини интерактивных рассказов XXI века вольны в своём выборе, они ищут и могут менять партнёров. Фольклористом 
Линдой Дег описан спродуцированный сегодняшней коммерческой и массовой культурой сценарий т. н. романтической свадьбы Золушки (Dégh 2003: 39-41), что в девичьих романтических рассказах также выступает в качестве одной из популярнейших концовок. Сегодняшние девичьи романтические рассказы - это истории об исполнении желаний. Они напоминают современные сказки и занимают место в одном ряду с созданными торговлей и индустрией гламура успешными историями о девушках, мечты которых сбываются, которые находят себе известных и богатых принцев и становятся принцессами.

\section{Примечания}

1 Просматривать многие из этих источников непросто, поскольку для этого требуются адреса и пароли. В последние годы данная традиция на rate.ее ослабла, большинство пользователей-подростков покинуло сайт.

2 Материалы хранятся в Эстонском фольклорном архиве: серия RKM KP, тома 25 и 40; серия EFA AK, тома 21 и 161; серия EKRK I, том 96.

${ }^{3}$ Данный рассказ и некоторые последующие рассказы в оригинале имеют названия на английском языке.

${ }^{4}$ Романтические рассказы в блогах девочек на сайте rate.eе собраны мной в личном архиве в порядке их публикования на сайте. Многие рассказы с продолжением за 2010-2011 и 2013 гг. уже не доступны на rate.eе. Ссылки на них даны по дате поступления и номеру страницы в собрании автора статьи.

5 Rate.eе - это эстонская социальная сеть, созданная в 2002 г. Андреем Коробейником. Портал был особенно популярен среди молодых интернет-пользователей. В первые годы существования сайта число зарегистрированных на rate.ее пользователей в возрасте 10-14 лет составляло почти 100 \% от количества жителей Эстонии этого возpacта: http://www.rate.ee/ads.php?act=1 (дата обращения 15.11.2017). На сегодняшний день эта сеть утратила свою популярность среди девочек.

6 О представлении любви в советской культуре см. Борисова \& Богданов \& Мурашов 2008.

7 Из блога пользователя Redplix на rate.ee, 2011, февраль, с. 33. 
8 Популярный анонимный эротический рассказ конца XIX - начала $\mathrm{XX}$ века. Происхождение и точное время написания текста неизвестно, распространялся путём переписывания. Авторство приписывалось многим известным русским писателям, но наиболее вероятным автором считается всё-таки Алексей Николаевич Толстой. Не исключено, что рассказ, имитирующий более ранний литературный стиль, был написан в 1930-е годы как своеобразная реакция на табуирование секса в советской литературе (ru.wikipedia. org/wiki/Баня_(рассказ).

9 Из блога пользователя Vivvz на rate.ee, 2013, февраль, с. 10.

${ }^{10}$ Из блога пользователя Redplix на rate.ee, 2011, март, с. 17.

${ }^{11}$ Из блога пользователя Reeli на rate.ee, 2011, декабрь, с. 20.

${ }^{12}$ Из блога пользователя PinkCat на rate.ee, 2013, февраль, с. 35.

${ }^{13}$ Из блога пользователя Vivvz на rate.eе, 2013, февраль, с.13.

${ }_{14}$ Жизнь Элеанор, https://www.facebook.com/search/top/?q=eleanori\%20 elu; Рассказы Шакир, https://www.facebook.com/shakira.randjarv (дата обращения 15.11.2017).

${ }^{15}$ Жизнь близнецов, https://www.facebook.com/AinultLahedadTydrukud/ (дата обращения 15.11.2017).

16 Занилательная жизнь Мелиндь, https://www.facebook.com/search/ top/?q=j\%C3\%A4rjejutt\%3A\%20melinda\%20p\%C3\%B5nev\%20elu (дата обращения 15.11.2017).

${ }^{17} \mathrm{http}$ ://www.rate.ee/blog/1440236/we-are-a-love-story-gone-wrong-32ehk-viimane (дата обращения 15.11.2017).

\section{Литература}

Anttila, Anna 1996. 99 prosenttia rakkautta. Tyttöjen ennustusleikit opetavat seurustelu sääntöja. Kinnunen, Eva-Liisa \& Koski, Kaarina \& Penttilä, Riikka \& Pietilä, Minttu (ред.). Vitsistä videoon. Helsinki: Suomalinsen Kirjallisuuden Seura, cc. 35-52.

Anttila, Anna 2009. Leikin asia. Näkokulmia varhaisnuorten romanttiseen seurustelukulttuuriin. Helsinki: Yliopistopaino.

Belsey, Catherine 1994. Desire. Oxford and Cambridge: Blackwell. 
Борисова, Наталия \& Богданов, Константин \& Мурашов, Юрий 2008. СССР: Территория любви. Новые материаль и исследования по истории русской культуры 06. Москва: Новое издательство.

Борисов, Сергей 1992. Тридиать девичьих рукописньх рассказов о любви. Обнинск.

Борисов, Сергей 2002. Мир русского девичества. 70-90 годь XX века. Москва: Научно-издательский центр «Ладомир».

Dégh, Linda 1994. Beauty, Wealth and Power: Career Choises for Women in Folktales, Fairy Tales and Modern Media. American Folklore and the Mass Media. Bloomington and Indianapolis: Indiana University Press, cc. 180-209.

Gaunt, Simon 2006. Love and Death in Medieval French Literature: Martyrs to Love. Oxford and New York: Oxford University Press.

Illouz, Eva 1997. Consuming the Romantic Utopia. Love and the Cultural Contradictions of Capitalism. Berkeley, Los Angeles and Oxford: University of California Press.

Illouz, Eva 2013. Ist die Liebe tot? Die Zeit/Philosophie, June. http://www. zeit.de/2013/25/eva-illouz-liebe-tot.

Kalmre, Eda 1997. This long short way from the memory album to the oracle. Girls' written lore of the years 1970 to 1990. Journal of the Baltic Institute of Folklore 1, cc. 97-112.

Kalmre, Eda 2010. Tüdrukute materjalikogudest ja eneseesitlusest internetis rate.ee päevikute armastusjutustuste näitel. Kalmre, Eda (ред.). Tulnukad ja internetilapsed. Uurimusi laste- ja noortekultuurist. Tartu: EKM Teaduskirjastus, cc. 214-245.

Корсаков, Дмитрий 1994. Она лежала на асфальте, как белый лебедь... Колсолольская Правда, 11 октября.

Лебина, Наталья 2014. Мужчина и женщина: Тело, мода, культура. СССР- оттепель. Москва: Новое литературное обозрение.

Lipponen, Ulla 1992. Ruusu ja rikkaruoho. Rakkaus tyttöjen runovihkoperinteessä. Näre, Sari \& Lähteenmaa, Jaana (ред.). Letit Liehumaan. Tyttökultuuri murroksessa. Helsinki: Suomalaisen Kirjallisuuden Seura, cc. 114-134. 
Mattheus, Ave 2010. Noor(te)kirjanduse plahvatus. Looming 9. www. looming.ee/index2.php?archive_mode=article\&articleid=455 (дата обращения 06.10.2014).

Шикаренко, Юрий 1995. Рукописные рассказы о любви. Урал 12, cc. $12-85$.

Жаворонок, Светлана 1998. Девичьи рукописные любовные рассказы. Борисов, Сергей (сост). Русский школьный фбольклор. Москва: Научно-издательский центр «Ладомир».

\section{Summary}

\section{Girls' Self-created Love Stories: Romantic, Ideals, Examples, Evolution}

\section{Eda Kalmre}

Keywords: album, blog, personal manuskript collection, girls' literature, girls' subculture, internet, lovestory, romance

The article is based on interactive love stories collected from 14-18-year-old Estonian girls' blogs starting from 2010, and partly also on girls' manuscript material from the second half of the 20th century, employed mainly to provide a historical and comparative perspective for the contemporary interactive material. Contemporary material mainly originates from the social network portal rate.ee, and as of 2014 it has been supplemented by love stories published in dedicated Facebook communities. The aim of the article is to give an overview and analyse how these stories reflect concepts of couple relations, romance, love, happiness and dreams of future. An attempt is made to see how girls' fantasies correspond to contemporary general cultural concepts of romance, love and sex. 


\section{МИССИЯ ВЫПОЛНИМА Перспективы изучения фольклора}

http://www.folklore.ee/rl/pubte/ee/sator/sator19/

ISSN 1736-0323

ISBN 978-9949-586-60-8

DOI: $10.7592 /$ Sator.2018.19

Тарту 2018

Редакторы-составители выпуска:

Маре Кыйва \& Татьяна Володина

Редактор серии: Маре Кыйва

Фото: Яак Кикас, 2018 «Осень в Тарту»

Оформление обложки: Лииса Весик

Верстка \& HTML: Диана Кахре

Печатное издание: МИССИЯ ВЫПОЛНИМА:

Перспективы изучения фольклора. SATOR 19. Тарту 2018

Публикация книги осуществлена совместно Эстонским литературным музеем и Центром исследований белорусской культуры, языка и лит ерат уры Националь ной акад емии наук Б еларус и, п ри поддержке Министерства образования и науки Эстонии (IUT 22-5), Фонда регионального развития ЕС (ТK 145, Центр компетенции по Эстонским исследованиям); при поддержке проекта, финансируемого Министерством иностранных дел Эстонии из бюджета по сотрудничеству и развитию, Эстонской Академией Наук и Национальной академии наук Беларуси.

Оформление электронного издания осуществлено при поддержке проекта ЕККМ14-344 “Расширение областей применения и представление эстонского языка, культуры и фольклора в электронных информационных средствах".

() Эстонский литературный музей

(c) Авторы

(с) Яак Кикас 